\title{
Próun aðferðafræði fyrir mat á tæknilega mögulegu vatnsafli með notkun vatnafræðilíkana í hárri upplausn
}

\author{
Tinna Pórarinsdóttira , Sigurður Magnús Garðarsson ${ }^{b}$, Philippe Crochet ${ }^{a}$, Hrund Ólöf Andradóttir ${ }^{b}$ \\ a Veðurstofa Íslands, Bústaðavegur 7-9, 150 Reykjavík \\ Fyrirspurnir: \\ b Umhverfis- og byggingarverkfræðideild, Háskóli Î́slands, Hjarðarhagi 2-6, 107 Reykjavík. \\ Tinna Pórarinsdóttir \\ tinna@vedur.is \\ Greinin barst \\ 26. september 2012. \\ Sampykkt til birtingar \\ 12. júní 2013.
}

\section{ÁGRIP}

ABSTRACT

Rafmagnsframleiðsla Íslendinga kemur að stórum hluta frá vatnsorku. Nú eru liðin rúm 30 ár frá pví aðo sî̉ast var lagt mat á vatnsafl landsins og á peim tíma hafa orðið tæknilegar framfarir sem kalla á endurnýjun pessa mats. Markmið pessarar greinar er að lýsa próun á aðferðafræði sem nota má við útreikninga og kortlagningu tæknilega mögulegs vatnsafls par sem próuð hafa verið vatnafræðileg líkön í hárri upplausn, eins og er tilfellið á Íslandi. Dagleg meðalgildi rennslis fengust á reglulegu reiknineti með $1 \mathrm{~km}$ upplausn með hjálp vatnafræðilíkansins WasiM. Rennsli í farvegum var reiknað skv. rastagögnum úr ArcGIS gagnagrunni Veðurstofu Íslands um yfirborðshalla og samsöfnun rennslis. Úrkomugögn voru einnig notuð sem ígildi rennslis til pess að greina áhrif pess að nota margpætt vatnafræðilíkan fram yfir óbreytt úrkomugögn. Bæði var gert ráð fyrir miðluðu og ómiðluðu rennsli með pví að nota mismunandi hlutfallsmörk á langæislínu sem rennslismat. Mat á mögulegu vatnsafli fór fram fyrir hvern reit sem staðsettur er í rennslisfarvegi innan reikninets með $25 \mathrm{~m}$ upplausn. Tæknilega mögulegt vatnsafl er heildarvatnsafl miðað við fullkomna nýtni, án pess að gert sé ráð fyrir neinum takmörkunum, svo sem vegna náttúruverndar eða annarrar landnýtingar. Í pessari grein eru niðurstöður mats á mögulegu vatnsafli á vatnasviði Dynjanda á Vestfjörðum kynntar.

Lykilorð: Vatnsafl, vatnafræðilikön, tæknilega mögulegt vatnsafl, vatnasvið
A large portion of the total electricity production in Iceland originates from hydropower. The last estimation of the hydropower potential was conducted thirty years ago, in 1981. Since then, there have been major technical developments that call for a renewal of estimation of hydropower potential. The aim of this paper is to describe the development of a methodology that can be used for calculating and mapping technical hydropower potential where high resolution hydrological models are available, as is the case for Iceland. Average daily discharge was provided on a gridded form with $1 \mathrm{~km} 2$ resolution by the hydrological model WaSiM. The discharge was routed along the river channel using information about slope and flow accumulation from the ArcGIS database at the Icelandic Meteorological Office. Gridded precipitation data was also routed and used as a proxy for runoff in order to study the benefit in using an advanced hydrological model rather than a crude estimate of the water input onto the catchment. Both regulated and unregulated discharge was accounted for in the methodology by using different quintiles of a flow duration curve (FDC) derived from estimated discharge. The potential hydropower was estimated for each grid cell along the river network with a resolution of $25 \mathrm{~m}$. The technical hydropower potential represents all potential hydropower with full efficiency and without assuming any limitations, such as environmental protection or other land use. Results of hydropower potential estimated for the catchment of Dynjandi River in Iceland are presented.

Keywords: Hydropower, hydrological models, technical hydropower potential, catchment

\section{Inngangur}

Vatnsaflið er ein mikilvægasta orkulind Íslands, pað stendur undir u.p.b. $73 \%$ af heildar raforkuframleiðslu landsins (Haukur Eggertsson, Ívar Porsteinsson, Jónas Ketilsson \& Ágústa Loftsdóttir, 2010). Nýtanlegt vatnsafl er margfeldi af fallhæð og rennsli í gegnum hverfil ásamt stuðlum sem taka tillit til nýtni kerfisins og pyngdarhröðunar,

$$
\mathrm{P}=\eta \gamma \mathrm{QH}
$$

par sem P er vatnsaflið, h er nýtni, g er eðlispyngd, Q er rennsli í gegnum hverfilinn og $\mathrm{H}$ er heildar fallhæð.

Við mat á vatnsafli er pví nauðsynlegt að afla upplýsinga varðandi fallhæð annars vegar og rennsli hins vegar. Rannsóknir á möguleikum vatnsafls krefjast enn fremur greiningar á peim páttum í umhverfinu sem hafa áhrif á fallhæð og rennsli. Landfræðileg upplýsingakerfi (LUK) ásamt fjarkönnun hafa á sídustu árum próast sem helstu hjálpartæki við myndun pekkingargrunns fyrir mat og stjórnun ýmissa umhverfispátta og eru saman notuð víða við kortlagningu á mögulegu vatnsafli. Fallhæð má mæla beint eða nota til pess sjálfvirkar aðferðir með stafrænu hæðarlíkani. Rennsli er hins vegar hád sampættingu mismunandi ferla í náttúrunni á hverju vatnasviði fyrir sig. Helstu áhrifapættir rennslis eru úrkoma, snjó- og ísbráđnun, grunnvatns- straumar, uppgufun og útgufun og getur pví reynst erfitt að meta rennslispáttinn. Pessa áhrifapætti parf að greina og meta. Rennslismælingar fara oftast fram á einum eða fleiri stöðum innan vatnasviða. Rennslismat er pó nauðsynlegt ef krafist er rennslisupplýsinga eftir endilöngum farvegum tiltekins vatnasviðs, eða ef rennslismælingar eru ekki nægjanlegar eða jafnvel ekki til staðar. Í pessum tilfellum er notað vatnafræðilíkan til að herma vatnsbúskap vatnasviðsins. Gerð líkansins er háð parfagreiningu hvers verkefnis.

Með aukinni áherslu á endurnýjanlega orku á síðustu árum hafa fjölmargar rannsóknir farið fram varðandi mat á vatnsaflsauðlindum um allan heim. Kanadísk rannsókn um kortlagningu vatnsaflsauðlinda í New Brunswick byggir á notkun tölvugerðs farvegakerfis sem kallað er "synthetic hydro network" ásamt árlegu meðal- og grunnrennsli (Cyr, Landry \& Gagnon, 2011). Meðalrennsli er notað við mat á hefðbundnu vatnsafli með miðluðu rennsli en grunnrennslið við mat fyrir rennslisvirkjanir. Bandarísk rannsókn frá árinu 2004 miðaði að mati á vatnsafli með áherslu á lága fallhæð og par með lægri orkumöguleika en stærstu virkjanirnar bjóða upp á (Hall, o.fl., 2004). pannig var mögulegt vatnsafl metið fyrir hvern hluta vatnsfalls sem var af meðallengd tvær mílur, eða um 3.219 m. Árlegt meðalrennsli var metið með aðhvarfsgreiningu sem próuð var fyrir hvert svæði og fallhæð reiknuð með notkun stafræns hæðarlíkans. Eins hefur farið 
fram rannsókn í Noregi par sem metnir eru möguleikar minni vatnsaflsvirkjana (Voksø, o.fl., 2004). Rennslið var metið með afrennsliskorti og fallhæð reiknuð út frá hæðarlíkani með pví að fikra sig eftir farvegakerfinu og framkvæma útreikninga á fallhæð með $50 \mathrm{~m}$ millibili. Afrennsliskortið var unnið úr Hydrologiska Byråns Vattenbalansavdelning (HBV) vatnafarslíkaninu (Bergström, 1976). Líkanið var notað í $1 \mathrm{~km}^{2}$ upplausn til pess að meta mánaðarlegt afrennsli sem síðan var notað til að reikna meðalársafrennsli fyrir útreikninga á vatnsafli. Allar fyrrnefndar rannsóknir hafa pað sameiginlegt að pær miða að pví að kortleggja mögulegt vatnsafl en leysa verkefnið á mismunandi hátt, háð parfagreiningu og tiltækum gögnum á hverjum stað fyrir sig.

Vatnsaflsauðlindin hefur nokkrum sinnum verið metin hérlendis. Jón Porláksson mat hana fyrstur árið 1920 með pví að meta vatnsaflið í úrkomunni og giska á hversu stór hluti pess væri nýtanlegur. Niðurstaða pess mats var að nýtanleg vatnsorka væri 26 TWh/ári (Haukur Tómasson, 1981). Sigurður Thoroddsen lagði mat á vatnsafl landsins árið 1962. Hann gerði ráð fyrir ákveðnum virkjanakostum, mat orkuvinnslugetu peirra og lagði saman til pess að fá heildarmat á vatnsafli, samtals 35 TWh/ári. Árið 1981 kynnti Haukur Tómasson (1981) niðurstöður sínar við mat á vatnsafli landsins. Matið byggðist á skiptingu landsins í reiti með möskvastærð 10-12 km. Meðalhæð reitanna var pekkt út frá mælingum á pyngdarsviði landsins en afrennsli peirra var áætlad annars vegar út frá pví hvar úrkoman félli og hins vegar hvar vatnið kæmi fram sem yfirborðsrennsli. Afrennslis- og landhæðarupplýsingar reitanna voru svo notaðar til pess að meta vatnsafl í sniðpunktum fyrir hverja $5 \mathrm{~km}$ eftir farvegakerfi sem unnið var upp úr kortum í mælikvarða 1:250000 (Kristinn Einarsson, 1999). Niðurstöður gáfu 64 TWh/ári og par af 33 TWh/ári sem féllu undir hagkvæma vatnsorku með meira en 150 GWh/ári í sérhverjum sniðpunkti (Haukur Tómasson, 1981).

Á peim 30 árum sem liðin eru frá síðasta mati hafa orðið fjölpættar framfarir hvað varðar gæði gagna og próun gagnagrunna með landfræðilegum upplýsingakerfum (LUK) og vatna- og straumfræðilegum rannsóknum. Pessar framfarir kalla á endurnýjun á vatnsaflsmati landsins, enda má ætla að betri tækni og aukin pekking skili nákvæmari niðurstöðum mats á vatnsafli. Enn fremur er rétt að undirstrika nauðsyn pess að fyrir liggi nákvæmar upplýsingar um heildarmat og kortlagningu á vatnsafli landsins í allri umræðu og ákvarðanatöku um verndar- og nýtingaráætlanir. Rannsókn pessari er ætlað að lýsa próun á aðferðafræði sem má nota við endurnýjun á vatnsaflsmati landsins skv. bestu fáanlegu opinberu gögnum hérlendis. Aðferðafræðina má nota við bæði útreikninga og kortlagningu tæknilega mögulegs vatnsafl á Íslandi. Hér verður aðferðafræðin rakin í stórum dráttum og gerð grein fyrir notkun rennslisgagna og upplýsingum um fallhæð. Kynntar eru niðurstöður mats á tæknilega mögulegu vatnsafli á vatnasviði Dynjanda á Vestfjörðum og mat lagt á helstu kosti og galla aðferðafræðinnar.

\section{Аðferðafræði}

Við útreikning á vatnsafli parf að meta eða reikna bæði fallhæð og rennsli. Til að reikna fallhæð voru notuð rastagögn úr ArcGIS gagnagrunni Veðurstofu Íslands (VÍ). Afrennsli var metið annars vegar með aðstoð vatnafræðilíkansins WaSiM (Schulla \& Jasper, 2007) og hins vegar með úrkomugögnum einum og sér með pví markmiði að greina áhrif pess að nota margpætt vatnafræðilíkan fram yfir óbreytt úrkomugögn. Reitaskiptum afrennslisgögnum var veitt í farvegi með notkun gagna um yfirborðshalla og samsöfnun rennslis (e. flow accumulation) til pess að fá rennslismat eftir endilöngum farvegum vatnasviðs en ekki einungis við rennslismæli. Gert var ráð fyrir bæði miðluðu og ómiðluðu rennsli með pví að nota mismunandi hlutfallsmörk á langæislínu (e. flow duration curve) sem rennslismat. Petta var gert með pví markmiði að aðferðafræðin gæti gefið upplýsingar miðað við rennslisvirkjanir jafnt sem virkjanir með miðlunarlóni. Tæknilega mögulegt vatnsafl var reiknað fyrir hvern reit sem staðsettur er í rennslisfarvegi innan reikninets með 25 m upplausn. Aðferðafræðin var prófuð á premur vatnasviðum af ólíkri stærð, staðsetningu og vatnafarslegum eiginleikum og með nýlega uppfærð afrennsliskort. Í pessari grein verða niðurstöður vegna mats á mögulegu vatnsafli á vatnasviði Dynjanda kynntar. Vinna má sambærileg gögn fyrir landið allt varðandi fallhæð en sambærileg rennslisgögn eru ekki tiltæk nema fyrir viss vatnasvið eins og er. Segja má að Vatnagrunnur VÍ annars vegar og afrennsliskortin hins vegar séu forsenda fyrir aðferðafræðinni sem próuð er. Frekari niðurstöður má nálgast í MS ritgerð Tinnu Pórarinsdóttur (2012).

\section{Reiknuð fallhæð}

Fallhæð var reiknuð samkvæmt rastagögnum úr ArcGIS gagnagrunni VÍ. Notuð voru gögn úr Vatnagrunni Ví til pess að kortleggja farvegi með $25 \mathrm{~m}$ upplausn og fallhæð reiknuð eftir endilöngum farvegunum. Vatnagrunnurinn geymir m.a. vatnafarsleg kortagögn fyrir landið allt sem eru rekjanleg frá upptökum vatnsfalla til árósa, s.s. staðsetningu árfarvega, samsöfnun rennslis og rennslisstefnu út frá landhæð (Bogi B. Björnsson \& Esther H. Jensen, 2010). Upplýsingar um samsöfnun rennslis voru notaðar til pess að fikra sig frá upptökum vatnasviðs til árósa og hæðarmismunur tveggja samliggjandi reita skrádur samkvæmt hæðarlíkani. Til pess að fullnýta mögulega upplausn var lágmarksfallhæð valin 1 m. Á mynd 1 má sjá alla pá staði eftir farvegum Dynjanda sem hafa $1 \mathrm{~m}$ fallhæð eða meira.

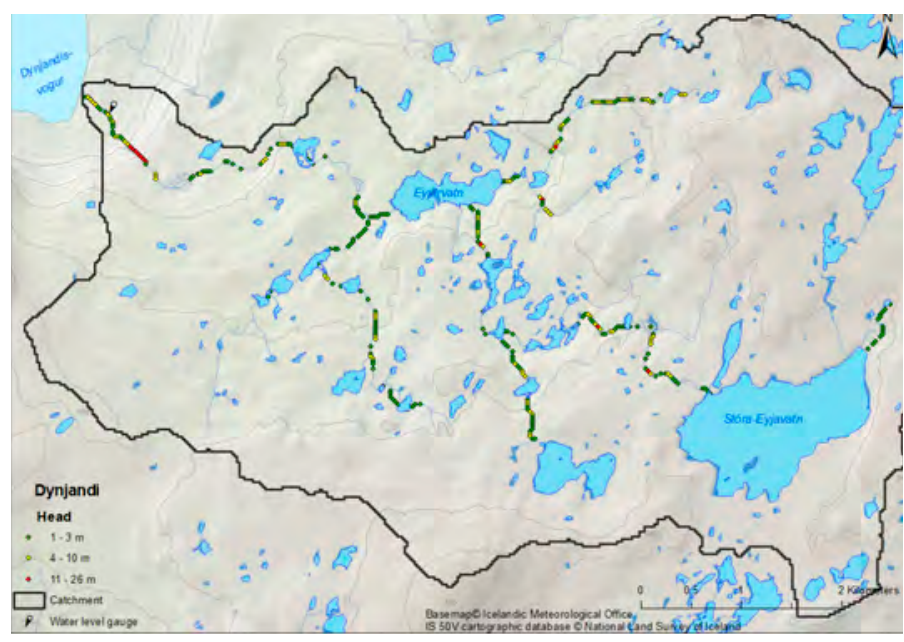

Mynd 1: Fallhæð eftir farvegum Dynjanda á Vestfjörðum.

\section{Metið rennsli}

Afrennsli var metið með aðstoð vatnafræðilíkansins WaSiM-ETH sem líkir eftir daglegum meðalgildum afrennslis á reglulegu reiknineti (Schulla \& Jasper, 2007). WaSiM líkanið er svissneskt reitaskipt vatnafræðilíkan sem notað hefur verið sídustu ár á ví (Jónsdóttir, 2007) við gerð afrennsliskorta með $1 \mathrm{~km}$ upplausn. Líkanið tekur inn ýmis gögn, s.s. jarðvegsgögn, landhæð, veðurgögn, gróðurfarsgögn, lekt o.s.frv. og er kvarðað út frá mældum rennslisröðum. Ýmsar framfarir hafa orðið varðandi notkun WaSiM líkansins hérlendis sî́ustu ár, m.a. má nefna hálf sjálfvirka kvöroun líkansins (Crochet, 2012; Auður Atladóttir, Philippe Crochet, Sveinbjörn Jónsson \& Hilmar B. Hróðmarsson, 2011) og hærri upplausn bæði úrkomu- (Crochet, o.fl., 2007) og hitastigsgagna (Crochet \& Jóhannesson, 2011). Notuð var rennslisröð sem spannar 10 ár frá 1992 til 2001. Petta tímabil var valið með pví markmiði að nota nýleg gögn og nægjanlega langt tímabil til pess að gefa áreiðanlega rennslisröð en pó án pess að valda töfum á vinnslu verk- 
efnisins. Við kortlagningu rennslis innan vatnasviða voru vatnafarsgögnin úr WaSiM samtvinnuð með upplýsingum úr Vatnagrunni Ví, en pessi gögn hafa ekki verið samnýtt ádur hérlendis. Ástæðan var sú að WaSiM líkanið gefur afrennsli á hverjum skilgreindum reit en gefur ekki upplýsingar um samsöfnun rennslis frá upptökum til árósa og pví nauðsynlegt að fá pær upplýsingar úr Vatnagrunninum. Vatnagrunnurinn byggir á $25 \times 25 \mathrm{~m}^{2}$ myndeiningum og pví voru afrennslisgögnin endurskilgreind fyrir sömu reitastærð. Vatnagrunnurinn geymir m.a. upplýsingar um rennslisstefnu hverrar myndeiningar, skilgreint út frá hæð og afleiddum halla nærliggjandi myndeininga. Með pessum upplýsingum má veita daglegum meðalgildum afrennslis niður eftir farvegum hvers vatnasviðs. Pá er gert rád fyrir að taftími (e. time of concentration) innan vatnasviðsins sé 24 klst eða minna. Með pessari aðferð má meta rennsli vatnasviðs allt frá upptökum til árósa. Mynd 2 sýnir dreifingu meðalrennslis í farvegum innan vatnasviðs Dynjanda.

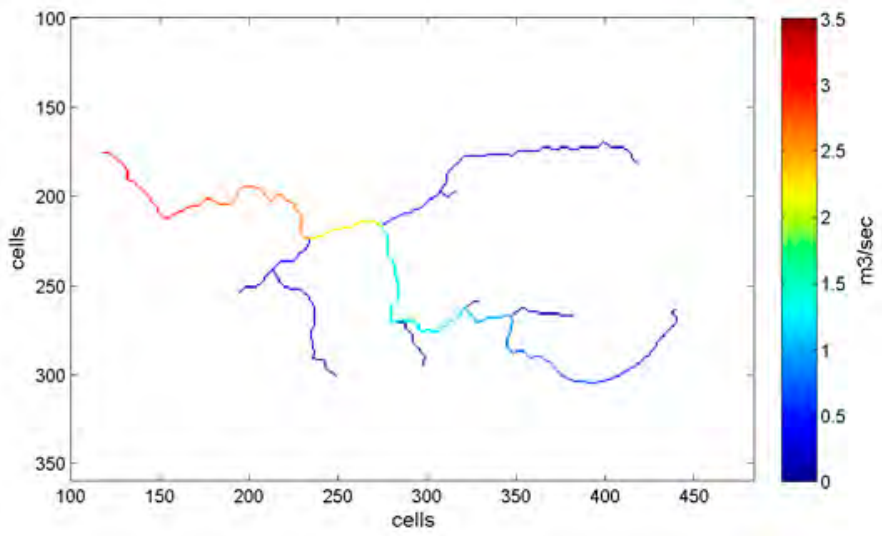

Mynd 2: Meðalrennsli í farvegum Dynjanda á Vestfjörðum.

Gert var rád fyrir bæði miðluðu og ómiðluðu rennsli með pví að nota mismunandi hlutfallsmörk á langæislínu sem rennslismat en langæislínan segir til um líkur pess að fá rennsli umfram tilgreint gildi. Efri hluti langæislínunnar sem nær yfir 50-100\% langæi má skilgreina sem lágrennslishlutann (Smakhtin, 2001). Sá hluti er pví notaður við mat á vatnsorku fyrir rennslisvirkjun (ómiðlað rennsli), en neðri hluti langæislínunnar (ca. 30-50\%) fyrir virkjun með miðlunarlóni. Langæislína er reiknuð fyrir hvern einasta reit innan farvegakerfisins í stað pess að miða rennsli innan vatnasviðsins við langæislínu við ós vatnasviðs. Á mynd 3 er rennsli í hverjum reit innan farvegarins fyrir prjá mismunandi

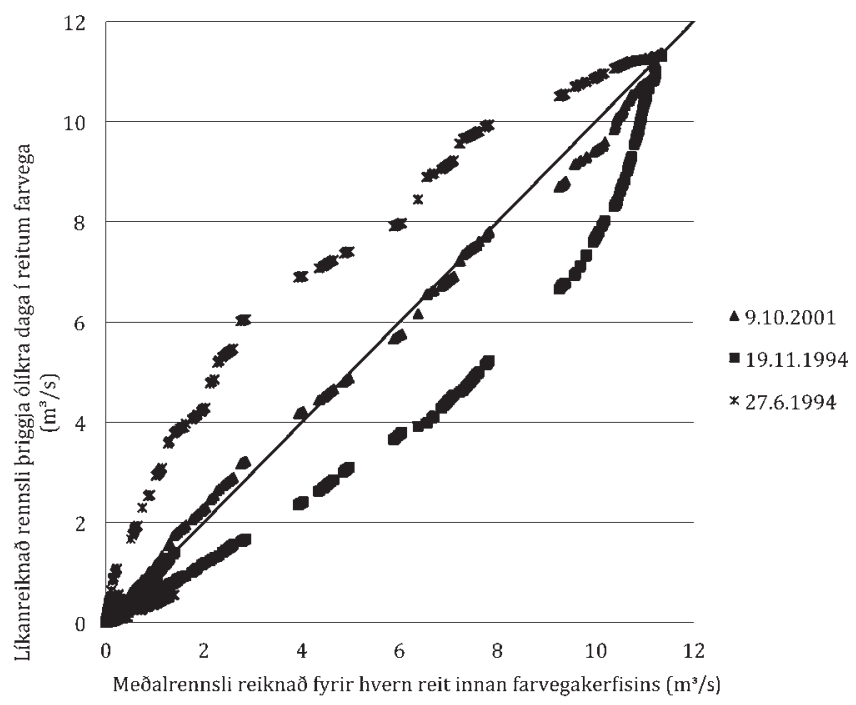

Mynd 3: Rennsli í hverjum reit miðað út frá meðalrennsli við ós vatnasviðs borið saman við reiknað meðalrennsli hvers reits. daga, pegar rennsli við ós er um $11 \mathrm{~m}^{3} / \mathrm{s}$ sem samsvarar meðalrennsli við ós viðkomandi vatnsfalls, plottað á móti reiknuðu meðalrennsli fyrir hvern reit innan farvegarins. Með pessu móti má sýna hvernig prír ólíkir dagar geta gefið sama heildarrennsli við ós prátt fyrir að rennsli innan farvegakerfisins sé ólíkt. Petta má rekja til pess að ólíkir pættir geta orsakað sama rennsli, s.s. rigning, snjóbráðnun o.s.frv. Pað má pví færa rök fyrir pví að eðlilegra sé að meta rennsli og langæislínu fyrir hvern reit eftir endilöngum farvegum vatnasviðsins heldur en að miða rennslið allt út frá einum og sama staðnum.

Við mat á rennsli var einnig prófað að notast við úrkomugögn ein og sér sem ígildi rennslis. Ljóst er að notkun óbreyttra úrkomugagna sem ígildi rennslis er takmörkunum hád en pó er ástæða til pess að greina áhrif pess að nota margpætt vatnafræðilíkan fram yfir óbreytt úrkomugögn, enda nýleg kvörðun vatnafræðilíkans ekki til staðar á öllum vatnasviðum landsins enn sem komið er. Sömu aðferðafræði var beitt á úrkomugögnin og notuð var fyrir afrennslisgögn úr WaSiM, rennslisstefnur úr Vatnagrunninum voru notaðar til að veita vatninu í farvegi og langæislínur reiknaðar fyrir hvern reit eftir farvegakerfinu. Nánari upplýsingar um WaSiM líkanið, aðlögun pess og rakningu rennslis í farvegi má finna í M.S.-verkefni Tinnu Pórarinsdóttur (2012).

\section{Niðurstöður og umræða}

Vatnsafl var reiknað skv. jöfnu (1) með u.p.b. 25 m millibili eftir endilöngum farvegum vatnasviðs Dynjanda á Vestfjörðum. Tæknilega mögulegt vatnsafl fæst í hverjum punkti sem hefur lágmarksfallhæð 1 m eða meira. Vatnsafl var reiknað með meðalrennsli og sex mismunandi hlutfallsmörkum langæis og pannig sýndir möguleikar miðlaðs og ómiðlaðs rennslis.

Niðurstöður eru birtar sem tæknilega mögulegt heildar vatnsafl sem og á kortum sem sýna tæknilega mögulegt vatnsafl eftir árfarvegum. Á myndum 4 og 5 má sjá kortlagðar niðurstöður fyrir vatnasvið Dynjanda bæði fyrir lágrennsli (hér 85\% langæi) og fyrir meðalrennsli. Eins og búast má við sýna niðurstöðurnar mun fleiri staði með tæknilega mögulegt vatnsafl sé miðað við meðalrennsli heldur en lágrennsli. Niðurstöður mögulegs heildarafls vatnasviðsins má sjá í töflu 1, par sem heildarafl fyrir meðalrennsli er 13,5 MW og tæp $4 \mathrm{MW}$ miðað við tiltekið lágrennsli. Niðurstöður fyrir heildarafl eru einnig gefnar að frádregnum peim reitum sem gefa minna en $10 \mathrm{~kW}$ og minna en 30 kW. Ólíklegt má telja að hagkvæmt sé að nýta vatnsafl af svo lítilli stærðargráðu, einkum innan við 10 kW, og pví gagnlegt að skoða hve stór hluti heildaraflsins fellur undir pann flokk.

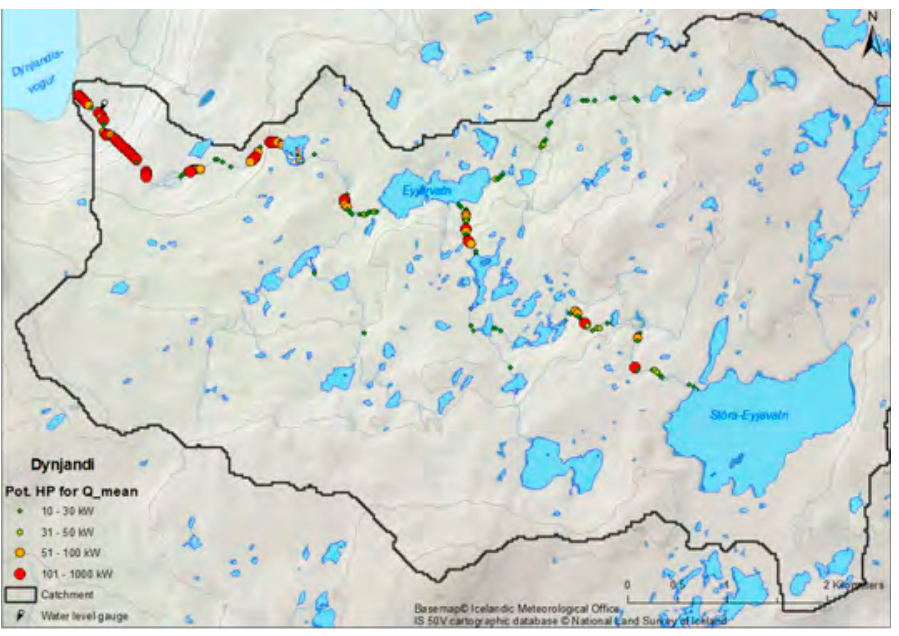

Mynd 4: Tæknilega mögulegt vatnsafl á vatnasviði Dynjanda, sé miðað við meðalrennsli eftir öllum farvegum. 


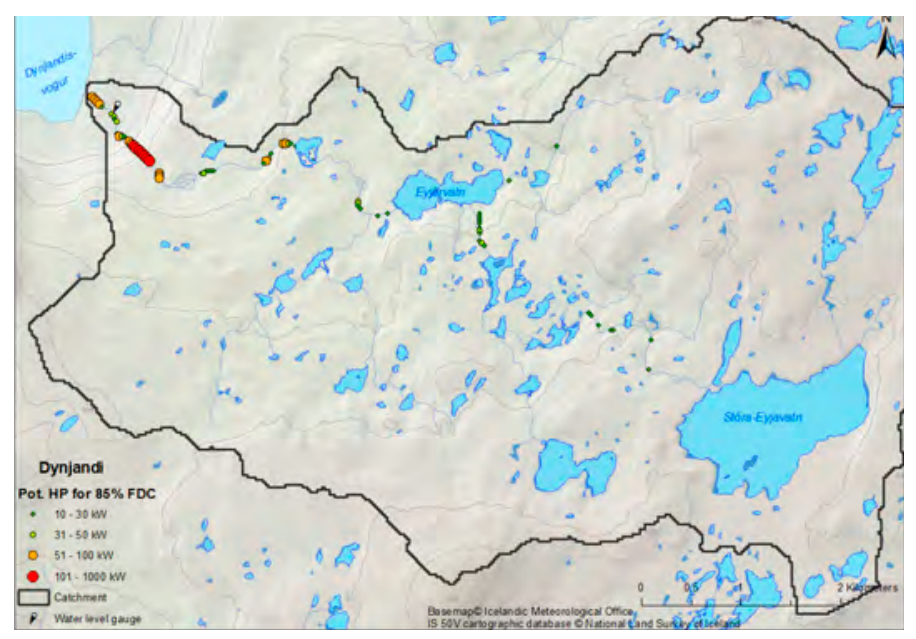

Mynd 5: Tæknilega mögulegt vatnsafl á vatnasviði Dynjanda, sé miðað við 85\% á langæislínu (lágrennsli).

Tafla 1: Niðurstöður heildarafls á vatnasviði Dynjanda, sé miðað við meðalrennsli eða $85 \%$ langæi.

\begin{tabular}{|c|c|c|c|}
\hline & Allir reitir & $\begin{array}{c}<\mathbf{1 0} \mathbf{~ k W} \\
\text { frádregið }\end{array}$ & $\begin{array}{c}<\mathbf{3 0} \mathbf{~ k W} \\
\text { frádregið }\end{array}$ \\
\hline $\begin{array}{c}\text { Heildarafl }[\mathbf{k W}] \text { fyrir } \\
\text { meðalrennsli }\end{array}$ & 13.575 & 12.958 & 11.094 \\
\hline $\begin{array}{c}\text { Heildarafl }[\mathbf{k W}] \text { fyrir } \\
\mathbf{8 5 \%} \text { langæi }\end{array}$ & 3.991 & 3.234 & 2.526 \\
\hline
\end{tabular}

Eins og búast mátti við reyndist erfitt að nýta hrein úrkomugögn í stað afrennslisgagna frá WaSiM. Á mynd 6 má sjá langæislínu við ós Dynjanda, annars vegar reiknaða með óbreyttum úrkomugögnum og hins vegar með afrennslisgögnum frá WaSiM. Niðurstöður sýna að úrkomugögnin gefa of hátt hárennsli og of lágt lágrennsli, eða í raun ekkert rennsli pann tíma sem engin úrkoma verður. Með pessu einfalda afrennslismati er ekki gerður greinarmunur á milli rigningar og snjókomu líkt og gert er innan WaSiM líkansins. Snjógeymsla og snjóbráðnun sem og aðrir pættir sem margpætt vatnafræðilíkön taka tillit til, skýra pví mismun á milli afrennslis með WaSiM og með óbreyttum úrkomugögnum. Eins er ekki gert ráð fyrir grunnrennsli með pví að nota einungis úrkomugögn og pví ljóst að grunnvatnsrík vatnasvið krefjast flóknari aðgerða. Notkun úrkomugagna eingöngu dugar pví ekki á tilteknu vatnasviði par sem vatnafræðilíkan er ekki til staðar, sérstaklega ef skoða á há- og lágrennsli fyrir mat á vatnsafli. Pað er pó mögulegt að endurbæta megi afrennslismatið með pví að meta pað ekki einungis út frá úrkomu heldur einnig með hitastigsgögnum

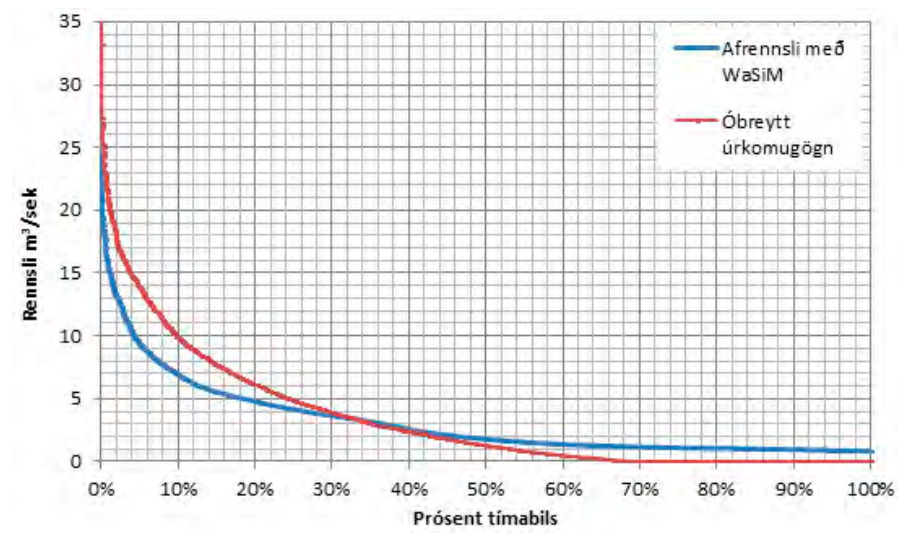

Mynd 6: Langæislínur við ós Dynjanda, reiknað með afrennsli frá WaSiM og með óbreyttum úrkomugögnum.
(Crochet, 2013). Pessháttar niðurstöður gætu nýst til bráðabirgða par til WaSiM líkanið hefur verið endurkvarðað fyrir öll vatnasvið skv. fyrrnefndum framförum varðandi notkun líkansins.

Sú aðferðafræði sem notuð er kortleggur tæknilega mögulegt vatnsafl allra árfarvega innan reikninets með $25 \mathrm{~m}$ upplausn og leggur svo saman til pess að fá heildarvatnsafl vatnasviðsins. Pað er mikilvægt að geta pess að sé gert ráð fyrir miðluðu rennsli með uppistöðulóni pá breytist bæði langæislínan neðar í ánni og fallhæðin eykst vegna lónsins. Petta er ekki tekið með í reikninginn í ofangreindri aðferðarfræði en má auðveldlega bæta við ef mögulegar útfærslur liggja fyrir. Pess ber einnig að geta að hér er um að ræða tæknilega mögulegt vatnsafl par sem gert er ráo fyrir fullkominni nýtni $(\eta=1)$ og engum árekstrum vegna ólíkrar landnýtingar og umhverfisverndar. Ekki er lagt mat á hagkvæmni miðlunarlóna, staðsetningar peirra eða á virkjunarkosti að neinu leyti. Pá er ljóst að 24 klst taftími innan vatnasviða getur valdið skekkju í rennslismati pegar kemur að stærri vatnasviðum. Pess má pó geta að verið er að próa áfram pá aðferðafræði sem lýst er hér með pví markmiði að komast hjá pví að veita vatninu í farvegi eftir landhæð. Pessi próun kæmi sér ekki einungis vel á stærri vatnasviðum par sem taftími getur verið lengri en 24 klst, heldur einnig á grunnvatnsríkum vatnasviðum par sem yfirborðs landhæð er ekki endilega ráđandi um rennslisstefnu.

Hvað varðar enn frekari vinnu við mat og kortlagningu vatnsafls, pá væri nauðsynlegt að nota lengri rennslisraðir til pess að fá bestu mögulegu heildarmynd af rennslinu. Ennfremur væri e.t.v. eðlilegt að hækka lágmarksfallhæð og takmarka pannig óvissu hæðargagna og jafnframt að skoða útreikninga á fallhæð og par með vatnsafli með lengra millibili eftir farvegakerfinu.

Aðferðafræðin er sambærileg peirri sem notuð hefur verið í Noregi (Voksø, o.fl., 2004) par sem metnir eru möguleikar minni vatnsaflsvirkjana, enda aðstæður um margt líkar í pessum löndum. Aðferðafræðin sem notuð hefur verið í Noregi nýtir pó grófara rennslismat par sem meðalársafrennsli er notað fyrir útreikninga á vatnsafli en ekki mismunandi hlutfallsmörk langæislínu líkt og hér er gert. Erfitt er að bera niðurstöður rannsóknarinnar við fyrra mat á vatnsafli hérlendis par sem aðferðafræðin hefur einungis verið prófuð á premur vatnasviðum enn sem komið er og skoðað er tæknilega mögulegt vatnsafl en ekki nýtanlegt líkt og í fyrra mati (Haukur Tómasson, 1981). Frekari umfjöllun um samanburð er að finna í MS ritgerð Tinnu Pórarinsdóttur (2012). Pó er ljóst að sú aðferðafræði sem beitt er nú nýtist betur en áđur fyrir bændur og aðra landeigendur par sem aðferðafræðin byggir á notkun gagna í hærri upplausn en í fyrra mati og gefur pví mun nákvæmari mynd af möguleikum smávirkjana en áđur. Ávinningur aðferðafræðinnar felst pví ekki síst í kortlagningu og framsetningu á dreifingu tæknilega mögulegs vatnsafls innan vatnasviða. Kortlagning sem pessi gefur ennfremur möguleika á pví að samtvinna ólíkar upplýsingar í gagnagrunnum svo auðvelt reynist t.d. að útiloka verndarsvæði við mat á mögulegu vatnsafli og eykur pannig möguleika á heildstæðu mati vatnsauðlindarinnar fyrir landið allt. Samsvarandi greiningar og lýst er hér að ofan voru gerðar fyrir vatnasvið Sandár í Pistilfirði og AustariJökulsár í Skagafirði. Pær niðurstöður má sjá í MS ritgerð Tinnu Pórarinsdóttur (2012). Unnið er að frekari próun og vinnslu aðferðafræðinnar sem nýst getur fyrir landið allt á Ví í samvinnu við Orkustofnun. Vatnagrunnur VÍ er tiltækur fyrir landið í heild og unnið er að endurkvörðun WaSiM líkansins fyrir öll mæld vatnasvið. Einnig er verið að próa aðferðafræði við mat á afrennsli ómældra vatnasviða.

\section{Samantekt}

Sett hefur verið fram aðferðafræði til mats á tæknilega mögulegu vatnsafli á Íslandi. Aðferðafræðinni var beitt á vatnasvið Dynjanda á Vestfjörðum. Niðurstöður sýna að mögulegt er að kortleggja tæknilega 
mögulegt vatnsafl á reiknineti með 25 m upplausn. Niðurstöður sýna einnig að notkun úrkomugagna sem ígildi rennslis koma ekki í stað margpætts vatnafræðilíkans líkt og WaSiM. Ennfremur kom í ljós að nauðsynlegt er að reikna langæislínu fyrir hvern reit innan farvegakerfisins í stað pess að miða rennsli innan vatnasviðsins við langæislínu við ós vatnasviðs. Aðferðafræði verkefnisins má nota á hverju vatnasviði landsins, eða á öll pau sem vatnafræðilíkani hefur verið beitt á. Ávinningur aðferðafræðinnar felst einna helst í kortlagningu tæknilega mögulegs vatnsafls í mun hærri upplausn en í fyrri rannsóknum hérlendis. Niðurstöðurnar geta nýst orkufyrirtækjum við skipulagningu stærri virkjana (>1000 kW) sem og fyrir bændur og aðra landeigendur við kortlagningu staða með möguleikum á smávirkjunum $(<100$ kW) og heimarafstöðvum $(<30 \mathrm{~kW})$. Niðurstöðurnar má flytja í Vatnagrunn VÍ og nota til frekari úrvinnslu og við mat á nýtanlegu vatnsafli.

\section{Heimildir}

Auður Atladóttir, Philippe Crochet, Sveinbjörn Jónsson \& Hilmar B. Hróðmarsson. (2011). Mat á flóðagreiningu með rennslisröðum reiknuðum með vatnafræðilíkaninu WaSiM. Frumniðurstöður fyrir vatnasvið á sunnanverðum Vestfjörðum. Reykjavík: Veðurstofa Íslands.

Bergström, S. (1976). Development and application of a conceptual runoff model for Scandinavian catchments. Norrköping: SMHI.

Bogi B. Björnsson \& Esther H. Jensen. (2010). Vatnagrunnur Veðurstofu Íslands. Reykjavík: Veðurstofa Íslands.

Crochet, P., Jóhannesson, T., Jónsson, T., Sigurðsson, O., Björnsson, H., Pálsson, F., Barstad, I. (2007). Estimating the spatial Distribution of Precipitation in Iceland Using a Linear Model of Orographic Precipitation. Journal of Hydrometeorology, 8, 1285-1306.

Crochet, P. \& Jóhannesson, T. (2011). A data set of gridded daily temperature in Iceland for the period 1949-2010. Jökull, 61.

Crochet, P. (2012). A semi-automatic multi-objective calibration of the WaSiM hydrological model. Reykjavík: Veðurstofa Íslands.

Crochet, P. (2013 (i prentun)). Sensitivity of Icelandic river basins to recent climate variations. Jökull, 63.

Cyr, J.-F., Landry, M. \& Gagnon, Y. (2011). Methodology for the large-scale assessment of small hydroelectric potential: Application to the Province of New Brunswick (Canada). Renewable Energy, 2940-2950.

Hall, D. G., Cherry, S. J., Reeves, K. S., Lee, R. D., Carroll, G. R., Sommers, G. L., Verdin, K. L. (2004). Water energy Resources of the United States with Emphasis on Low Head/Low Power Resources. Idaho National Engineer-
Reitaskiptar niðurstöður á kortum gera kleyft að draga frá verndarsvæði eða aðra staði sem uppfylla ekki ákveðin skilyrði fyrir raforkuvinnslu. Niðurstöðurnar sýna pannig hvernig færa má í nyt tækniframfarir síðustu ára við mat á tæknilega mögulegu vatnsafli hérlendis með notkun vatnafræðigagna og líkana í hærri upplausn en tíðkast hefur. Niðurstöður pessa verkefnis byggja pví grunn fyrir frekari vinnu við mat á mögulegu vatnsafli á Íslandi og stuðla að betra mati á bæði tæknilega mögulegu og nýtanlegu vatnsafli á Íslandi.

\section{Pakkir}

Petta verkefni var styrkt af Veðurstofu Íslands og af Orkustofnun. Höfundar eru pakklátir starfsmönnum beggja stofnana fyrir að deila pekkingu sinni og reynslu.

ing and Environmental Laboratory, Prepared for the US Department of Energy.

Haukur Eggertsson, Ívar Porsteinsson., Jónas Ketilsson og Ágústa Loftsdóttir. (2010). Energy Statistics in Iceland 2010. Sótt 11. janúar 2011 af http:// www.os.is/gogn/os-onnur-rit/orkutolur_2010-enska.pdf

Haukur Tómasson. (1981). Vatnsafl Íslands - Mat á stærð orkulindar. Orkuping. Orkustofnun, Vatnsorkudeild.

Jónsdóttir, J. F. (2008). A runoff map based on numerically simulated precipitation and a projection of future runoff in Iceland. Hydrological Sciences Journal, 53(1), 100-111.

Kristinn Einarsson. (1999). Verklýsingar fyrir nýtt mat á vatnsafli Íslands. Orkustofnun, Vatnamælingar.

Schulla, J. \& Jasper, K. (2007, November). Model Description WaSiM-ETH. Sótt 15. júlí, 2011, frá WaSiM-ETH: http://www.wasim.ch/downloads/doku/ wasim/wasim_2007_en.pdf

Smakhtin, V. (2001). Low flow hydrology: a review. Journal of Hydrology, 240(3-4), 147-186.

Tinna Pórarinsdóttir. (2012). Development of a methodology for estimation of Technical Hydropower potential in Iceland using high resolution Hydrological Modeling. MS ritgerð við Umhverfis- og byggingarverkfræðideild Háskóla Íslands.

Voksø, A., Stensby, H., Mølmann, K., Tovås, C., Skau, S. \& Kavli, O. (2004) Beregning av potensial for små kraftverk i Norge. Oslo: Norges vassdragsog energidirektorat.

\section{VERKH

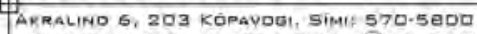

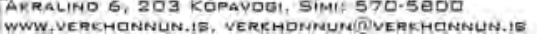
samSKIP
HS ORKA HF

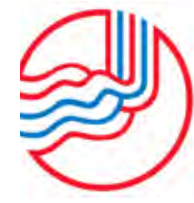
HS ORKAHF

\section{BLIKKSMIĐURINN PEKKING - FÆRNI - PJÓNUSTA}

